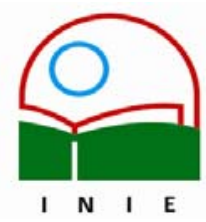

Universidad de Costa Rica

Facultad de Educación

Instituto de Investigación en Educación

ACTUALIDADES INVESTIGATIVAS EN EDUCACION

\title{
REFLECTIVE TEACHING AND ITS IMPACT ON FOREIGN LANGUAGE TEACHING
}

\begin{abstract}
Allen Quesada Pacheco ${ }^{1}$
To reflect is to look back over what has been done so as to extract the net meanings, which are the capital stock for intelligent dealing with further experiences. It is the heart of intellectual organization and of the disciplined mind. [John Dewey]

Resumen: Este artículo trata sobre la importancia que tiene la enseñanza reflexiva en el área de la enseñanza del inglés como segunda lengua. Además, se discute la importancia del pensamiento reflexivo como un elemento clave para mejorar y desarrollar la práctica profesional. Existe una necesidad de reflexionar sobre nuestras acciones y prácticas en el aula de lenguas extranjeras para poder ser capaces de disminuir la brecha entre la teoría y la práctica. Se define lo que es ser un maestro reflexivo y las ventajas que ello conlleva. Finalmente, se da un modelo de como la enseñanza reflexiva se puede visualizar y sugerencias prácticas de como aplicar esta
\end{abstract} teoría por medio de investigaciones en el aula.

Palabras clave: ENSENAÑZA REFLEXIVA/ ENSENAÑZA DEL INGLÉS COMO LENGUA EXTRANJERA/ PRÁCTICA PROFESIONAL/ ESL-EFL/

Abstract: This article deals with the impact of reflective teaching on the ESL/EFL field. Reflective thinking is seen as key on the road to professional growth. There is a need to reflect on our actions and classroom practices in the foreign language teaching in order to bridge the gap between theory and practice. A model is suggested as to how a teacher's practice in the classroom can be improved through reflective teaching and action research.

Keywords: REFLECTIVE TEACHING/ ENGLISH AS A FOREIGN LANGUAGE/ PROFESSIONAL DEVELOPMENT/ESL-EFL/

\section{Introduction}

When something goes wrong in our lives, our reaction should be to set a moment aside to think about why it happened, if we could have done something to prevent it, and how it might affect our future. These experiences usually make us grow. Hopefully, we will be better prepared to face the situation if it happened again. However, this is not always the case. This introspection is commonly called "reflection", and professionals have adopted it in order to improve their practice. For educators reflection involves "critical thinking" about past experiences or current experiences that occur or are occurring in classroom settings.

\footnotetext{
${ }^{1}$ Doctor of Philosophy in Curriculum and Instruction (Enseñanza del Inglés), University of Kansas (KU), E.E.U.U. Master of Arts in TESOL, New York University. Master of Science in Educational Technology, University of Kansas. Catedrático, docente e investigador. Vice- Decano de la Facultad de Letras de la Universidad de Costa Rica. Coordinador de la Comisión de Autoevaluación y Acreditación, Escuela de Lenguas Modernas.
}

Correo electrónico: allenq@cariari.ucr.ac.cr

Artículo recibido: 26 de julio, 2004

Aprobado: 28 de marzo, 2005 
Through reflection English as a Second Language or English as a Foreign Language (ESL/EFL) professionals can react, examine and evaluate their teaching to make decisions on necessary changes to improve attitudes, beliefs and teaching practices. This article examines the roots of reflective practice in foreign language teaching. It discusses the evolution of reflective thinking in teaching and the perspectives of different authors. At the same time, it debates over the importance of theory and practice, especially in language teaching development in the foreign language context. Added to this, this article addresses the need to implement reflective inquiry in classroom settings and ways to improve the teaching and learning of English as a Second or Foreign Language through on-going reflection.

\section{Historical background}

Reflective thinking is not an innovation in teaching. It has its roots in the work of a number of educational theorists and practitioners. The concept has been around for more than 50 years. Richardson (1990) has stated that John Dewey was already discussing it in 1909 by suggesting that "a moral individual would treat professional actions as experimental and reflect upon the actions and their consequences" (p. 3). Leitch and Day (2000) clarified Dewey's considerations by explaining that being an effective "reflective practitioner" is more than just improving practice and developing additional competence. It is more than that. A reflective practitioner should possess a set of attitudes towards teaching practice based upon broader understandings of self, society and moral purposes. This attitude involves stopping, slowing down, noticing, examining, analyzing and inquiring about aspects and complexities encountered in different situations.

Most definitions on reflective thinking found in the literature are based on Dewey's inquiry oriented concepts (Martin \& Wedman, 1988). Richardson (1990) has explained that it was in the 1970s that educators began to show interest for reflection and inquiry. It was then that qualitative research based on ethnography started to gain popularity. In turn, the beliefs and actions of teachers in the interactive learning process could be explored through an approach based on Dewey's ideas. Later on, in the 1980's, Donald Schön extended Dewey's foundational aspects on reflection. He coined two new concepts on reflective thinking: reflection-in-action and reflection-on action. According to Schön (1983), reflection-in-action relates thinking and doing. Schön explained that these two actions (thinking/doing) lead to modifying teaching practice with the purpose of improving learning. Reflection-in action is an 
internal conversation of the practitioner where he/she takes hold of the process/ or experience that has occurred, reframes it, and tries to experience it from a different perspective. He/she develops on-the-spot strategies of action to improve or adjust previous experiences. Thus, the "competent practitioner learns to think on his/her feet and is able to improvise as s/he takes in new information and/or encounters the unexpected" (Pickett, 1996, p. 1). Reflection-on-action, on the other hand, is viewed by Schön as 'teachers' thoughtful considerations and retrospective analysis of their performance in order to gain knowledge from experience" (cited in Leitch and Day, 2000). Pickett (1996) clarified that reflection-onaction is when "the practitioner reflects on the tacit understandings and assumptions s/he holds and subjects them to scrutiny in order to achieve deeper understanding of instructor/student roles, motivations and behaviors" (p.1).

Schön's distinctions in critical reflection has been investigated by Ross (1990) and Spraks-Langer and Colton (1991) by identifying five components of reflective thinking:

1. Recognizing an educational dilemma

2. Responding to a dilemma by recognizing both the similarities to other situations and special qualities of the particular situation

3. Framing and reframing the dilemma

4. Experimenting with the dilemma to discover the consequences and implications of various solutions

5. Examining the intended and unintended consequences of an implemented solution and reevaluating the solution by determining whether the consequences are desirable or not. (cited in Pickett, 1996, p.1)

In order to do this, educators are forced to look back into their own teaching practices, beliefs, attitudes, goals as well as those beliefs and attitudes of their students, of their colleagues, and of the teaching community itself. Educators, thus, need to be aware of the importance of the theory-practice relationship to really engage in reflective inquiry effectively and appropriately. This awareness will enable teachers to become thoughtful, as Dewey suggested, and learn from their work in light of purposes and principles that are "moral".

\section{Theory vs. practice}

Teachers around the world have different views about whether theory is more important than practice or vice versa. Some people would argue that in order to be able to teach effectively, teachers must posses a rich background knowledge, while others would claim that 
theory does not guarantee a good performance, that knowledge is acquired by doing. Both arguments are valid. The key to effective teaching is definitely a balance between theory and practice. Collin (1996) has said that some practitioners are skeptical about the value of theory and question its relevance, mainly because they do not how to use it. I think that theory is important not only to perform well, but also to be able to answer students' questions. For example, language teachers need to know about language acquisition theory to be able to explain students' behavior and help them in the learning process. At the same time, theorists need to be exposed to have first-hand experience in which to base or apply their research. The lack of one element makes the other one meaningless. I agree with Dahlin (1996) in that

we need to demonstrate our research base by conducting our own classrooms research (reflective practice) and by reading, using, and citing professional journals. The time has passed when teachers can simply say, 'It works.' We have to show that we understand the hows and whys of our theory and practice. (p. 57)

Imel (1992) has suggested ways for understanding these hows and whys:

- Questioning what, why and how one does things and asking what, why, and how others do things

- Keeping an open mind

- Comparing and contrasting

- $\quad$ Seeking the framework, theoretical basis, and/or underlying rationale

- Viewing from various perspectives

- $\quad$ Asking for others' ideas and viewpoints

- Using prescriptive models only when adapted to the situation

- Considering consequences

- Hypothesizing

- $\quad$ Synthesizing and testing

- Seeking, identifying and resolving problems (p.4)

Indeed, these strategies or processes will help teachers reveal any type of discrepancy between theory and practice. It will also bridge the gap among educators who tend to implement teaching practices without understanding why, and those who know why certain types of teaching practices should be implemented but do not know how. That is why two different types of educators are found in higher education settings: those with a vast expertise on theory and research practices, but with difficulties in teaching practices; and those novice professionals who can implement innovative and wonderful activities, but with little understanding about the rationale behind their teaching practices. Both types of professionals are missing one of the two components, theory and/or practice. Beyer (1984) 
has explained that situations like this (gap between theory and practice) occur because there is a tendency "to accept existing classroom situations as given, essentially unalterable, and beyond criticism" (p.38). He believes that once this happens, critical thinking or any other alternative possibility is considered useless or irrelevant. Therefore, many close-minded educators are reluctant to change. Perhaps the key to avoid this taken-for-granted attitude is to prepare teachers for the possible situations they will encounter and train them with teaching tools so that they can deal with these problems before they enter the classrooms. I believe that if both pre-service and in-service teachers are aware of the benefits of reflection, and if they experience the potential of this process, the results would be overwhelming as it would narrow the gap between theory and learning and would ensure more effective and selfconfident instructors in the field of ESL/EFL. This is highlighted by Richert (1990) in the following statements:

The ability to think about what one does and why - assessing past actions, current situations, and intended outcomes- is vital to intelligent practice, practice that is reflective rather than routine. As the time in the teaching process when teachers stop to think about their work and make sense of it, reflection influences how one grows as a professional by influencing how successfully one is able to learn from one's experience (p. 509).

In sum, linking theory and practice through reflective inquiry brings flexibility in instructional settings by helping practitioners examine successes and failures in a constructive environment and promote self-awareness and knowledge through personal experience. It also provides practicality because it not only asks practitioners to make connections between their beliefs and what really is happening in different contexts, but also involves those types of practitioners who teach in varied contexts and meet a great range of individuals with different styles of learning. Thus opportunities to explore and reflect on techniques, ideas and approaches are considered in the reflective process and immediate links between theory and practice are established. Added to this, linking theory and practice brings professionalism as a matter of promoting deliberate actions in planning, and as a way of implementing instructions and ongoing engagement with theory by assessing, revising and implementing new theories and practices. It also provides sustainability since time is allotted for reflection, implementation and follow-up practices (Florez, 2001). 
Reflective practice requires a commitment, a commitment towards change, towards understanding, and most importantly, a commitment towards continuous self-development. If practitioners are willing to invest time, effort and resources in this type of training, reflective practice can indeed be an effective means for professional growth.

\section{Reflective teaching as professional development}

Reflective teaching is beneficial for both pre-service and in-service teachers. Because it offers more advantages than disadvantages, teacher education programs are becoming more devoted to developing reflective practices in their student teachers. These programs seek to help novice teachers become more aware of decision-making processes to help them determine the effect their decisions have in the context in which they are implemented. So, experience previous to a "real job" prepares professionals for a better performance. Beyer (1984) has suggested,

As typically the final portion of the prospective teacher's professional preparation, it is expected to provide sufficient 'real life' experience to allow students to explore teaching methods and styles, connect 'theory' (chiefly learned in the college classroom) and 'practice' (mostly as experienced in a school setting), become familiar with the demands of teaching, and acquire the necessary skills and values needed to function adequately in that setting. Since the classroom is the arena within which students will presumably spend a major portion of their work lives, it seems reasonable to include experience of this sort as a prelude to their professional activities. (p.36)

Dewey (1933) has added that when teachers (novice or experienced) speculate, reason, and contemplate using open-mindedness, wholeheartedness, and responsibility, they will act with foresight and planning rather than basing their actions on tradition, authority, or impulse (cited in Cook, 1993). That is why, Dewey was among the first to promote reflection as a means of professional development in teaching. He believed that critical reflection is the most important quality a teacher (pre-service or in-service) may have and that it has much more impact on the quality of schools and instruction than the teaching techniques one uses.

It is very encouraging to know that teaching education programs usually include extensive field practice before student teachers take full teaching responsibilities. These field practices help pre-service teachers to analyze different types of methodologies and strategies of teaching as they go along in their training. However it is important to pinpoint that reflective 
inquiry should start at this stage (training stage). It is rarely done and the benefits pre-service teachers can obtain from this self-inquiry are valuable. As the student-teacher works with his/her mentor or training teacher, both share ideas, and through analysis, synthesis, evaluation, and reflection, the situations that are encountered in these field practices can be discussed and solved on the spot by means of reflection-in-action and reflection-on-action.

Zeichner and Liston (1987) have emphasized that when educational programs include reflective inquiry as part of their curriculum, these programs seek to train student teachers who

are willing and able to reflect on the origins and consequences of their actions...These goals are directed towards enabling teachers to develop pedagogical habits and skills necessary for self-directed growth and towards preparing them individually and collectively, to participate as full partners in their making of educational practices (cited in Richards, 2000, p.21)

Schön (1987) has called for the inclusion of reflective practices in education when he says: "the professional schools must rethink both the epistemology of practice and the pedagogical assumptions on which their curricula are based and must bend their institutions to accommodate the reflective practicum as a key element of professional education" (p. 18). The risk of not doing what Schön proposed is that practice "fossilizes." In fact, there are teachers who teach the same course several times, and they use exactly the same strategies throughout the years without considering the needs of students from group to group. They do not realize that these practices sometimes are to blame for the decline in students' achievement. However, many teachers still believe that the problem lies in the students' abilities, not in their teaching. That is why in-service teachers should be the first ones to view reflection and inquiry as key components of teacher development. In-service teachers cannot continue guiding their teaching practices by impulse or routine. Instead, they should bring a change in classroom settings guided by reflection, inquiry and critical thinking.

But how can this be done? Barlett (1990) have included a model of five elements in the cycle for the process of reflective thinking which in hand leads to professional growth to both pre-service and in-service practitioners. The model makes the teacher ask himself/herself questions such as "What do I do as a teacher?" in the mapping stage or preliminary stage, to self-inquire as an individual and internally observe beliefs, attitudes, methodologies, etc. In the second stage, informing, questions will be directed to the meaning of the teaching process itself, like, "What did I intend? With this question the teacher 
deepens into what his/her aims were in the teaching/learning process to determine successes or faults. When the practitioner asks him/herself questions like "How did I come this way?" or "How was it possible for my present view to have emerged?", then he/she is encountering the contesting stage which will oblige him/her to uncover situations and engage into discussions and reflection with colleagues by sharing ideas and thoughts. The fourth stage in this model deals with appraising, which is one of the most important stages because the teacher will inquire on new ways of teaching when he finds him/herself asking "How might I teach differently?" During this stage there is a growth towards innovative actions to improve problems encountered in previous experiences. At the end, Barlett suggested that practitioners should experience an acting stage as an on-going stage of action where new ideas arise in a continuing process every time this question is asked: "What and how shall I teach now?" This stage leads the reflective teacher to implement new practice, observe, analyze and evaluate it, and determine if the changes implemented have worked or not (cited in Pickett, 1996). Reflection is central in all of the stages of Barlett's model, and most significantly, as practitioners experience the stages, there is professional growth. This process will force teachers to step back and critically reflect not only on how they teach, but also why they teach in a particular way.

Simmons and Schuette (1988) provide a definition of the reflective teacher which evokes all the aspects involved in the process,

the truly reflective teacher is one who makes instructional decisions consciously and tentatively, critically considers a full range of pertinent contextual and pedagogical factors, actively seeks evidence about the results, and continues to modify these decisions as the situation warrants. (p. 20)

Teaching within the rationale of what responsible professional practice is, requires constant renovation. If teachers remain at a stage where practice is mechanical, without learning from their experiences in class and relating them to theory, their practice will never be considered professional. For Wallace (1991) a teacher education course should include two kinds of knowledge for it to be professionally structured:

a. Received knowledge. In this the trainee becomes acquainted with the vocabulary of the subject and the matching concepts, research findings, theories, and skills which are widely accepted as being part of the necessary intellectual content of the profession. 
b. Experiential knowledge. Here, the trainee will have developed knowledge-in-action by practice of the profession, and will have had, moreover, the opportunity to reflect on that knowledge-in-action.

In this case, experiential knowledge is not limited to practicing the received knowledge. It also includes reflecting on what is done. I remember that when I did my practicum, I received feedback forms from my professor who pinpointed the strengths and weaknesses of my lessons. Based on her comments, I tried to improve my teaching for the next session. However, I never really thought about why I was making the changes. I simply had been told to do so. Reflective teaching is not simply doing what you are being told to do. The practitioner should really dig and investigate the "why" something is wrong to make intelligent changes to teaching procedures. This understanding will interconnect received knowledge and experiential knowledge making the link mandatory for professional practice.

Aside from Barlett, Wallace (1991) also developed what he calls a "reflective model" applicable to both pre-service and in-service education. The model is separated it into three stages: the pre-training (trainee's existing conceptual schema or mental construct ), the professional development (theory and practice), and the professional competence (the ultimate goal).The difference between this model and other teacher-training models is what Wallace calls the "reflective cycle." There is a continuous relationship between reflection and practice. Moreover, this cycle allows for reflection both before and after practice. For example, English as a Second Language teachers can relate theory about interference of the native language on second language acquisition to why student " $X$ " is having trouble differentiating "he" and "she," and build on that to help him. Or, we can relate a given problem in the classroom to an article previously read. In short, knowledge makes sense when it can be related to immediate and/or past experience. At the same time, experience creates knowledge. Therefore, I think it is important to make both students and teachers familiar with reflective teaching, so that they can improve their performance and become respected, knowledgeable professionals of education who can account for their actions.

\subsection{Reflective teaching in foreign language contexts}

An unquestionable premise involving reflective teaching is that it facilitates meaningful thought and discussion among peers (teaching faculty) about teaching and learning that will inspire appropriate change in curriculum and pedagogy. In ESL/EFL contexts, these judgmental practices can impact positively in understanding what is going on in our 
classrooms and in producing changes in methodology, assessment, and instruction. Language teachers cannot see themselves as passive agents in the field. Rather, teachers should be involved deeply in the process, and the only way to do this is taking time to think and reflect on their practices to foster more effective learning in their students.

ESL/EFL teachers or any other teacher in the field of education bring to class personal beliefs about teaching; they bring to class personal styles for teaching, personal perceptions of students needs and even personal assumptions of what good teaching is. Some of the objectives of the reflective process is to deepen into what the teacher believes "good teaching" is, to mirror the teaching/learning process through different perspectives. Thus, the reflective practitioner visualizes through different eyes a picture of classroom environment and practices, and this awareness develops professional growth in his/her own teaching to make appropriate judgments and decisions. Pennigton (1992) has defined reflective teaching as that of "mirroring experience" and as the "input and output for development". She has proposed a reflective/developmental orientation as a turning point to improve classroom processes and outcomes and to develop self-confident and self-motivated teachers and learners through an ongoing and recursive cycle in the classroom (cited in Farrell, 1998).

What leads to reflection? Definitely our successes and failures in teaching practices. When teachers comment about their teaching practices as the following example statements, there is room for improvement: 'I used an information gap, but it did not work. Students couldn't perform the task. It was too difficult."; 'Students were lost; they couldn't understand what I was saying'; 'The opening of the class was confusing'; 'Students did not understand my instructions'; 'The activity was too long'; 'Students rarely talk. Am I doing most of the talking?'; "Most of the students fail on the test. I put things we had not practiced in class." These statements may lead to reflection. They are the starting point towards a positive pedagogy. Underhill (1991) has explained that teacher development is related to personal development, particularly personal development as a teacher. He has clarified that this process entails the teachers' personal choices about the way they think, feel and behave as teachers, and how teachers can become aware of the learning atmosphere they create and how the moment by moment choices they make can affect the learning environment of their students (cited in Miller de Arechaga, 2001). Unfortunately this practice rarely occurs at different levels of teaching (elementary, high school, university). Teaching is sometimes taken for granted and not as a means for growing pedagogically in the field. It is amazing what things can be observed in this reflective inquiry and how teaching procedures can be improved. Indeed, reflective teaching is enriching, empowering, and enduring. 
ESL/EFL teachers encounter many issues in classroom settings. Most of the rich data of classroom occurrences is mostly gathered by the instructor himself/herself. Other contributors are peers, teacher trainers, students themselves (one of the richest data is obtained through them). However, these occurrences are seldom detected or immersed in some sort of reflection. Many ESL/EFL teachers are more interested in completing the lesson plan they have organized (regardless its effectiveness) and never stop and reflect. Their daily lessons can be observed from different perspectives to gain insights on understanding their own teaching (through analysis and interpretation) as well as the effect teaching has on students, positively or negatively.

Wajnryb (1999) has explained that observing our own teaching is a way of discovering the classroom from a perspective other than the one we actually engage in; it is a way of providing focus and clarity; it is a means of collecting classroom-observation data and information about teaching. Self-observation provides meta-language to teachers ( $a$ language to talk about with other colleagues about classroom situations and procedures). She has highlighted that it promotes a raised awareness of classroom realities and a 'reservoir of information and experiences' that will direct ESL/EFL teachers towards discussions and reflections of classroom situations with peers, and the decisions taken would be more informed and systematic. Added to this, reflective observation builds the groundwork for better relationships among colleagues based on mutual support and respect.

A way to ensure positive changes in English Language Teaching (ELT) is through the formation of reflective inquiry groups. These are formed by faculty staff members who show respect, mutual growth and understanding on issues encountered in class such as students' learning styles/, their needs, wants and lacks; and assessment instruments, among other aspects. Through this cycle, teachers can identify an issue or question to bring before the group and with the help of other colleagues, a thorough description and analyses of the issue takes place. Discussions occur and a series of interpretations are brainstormed with the purpose of planning actions that might lead to successful teaching practices. Amazingly, a great number of issues arise through reflective inquiry groups. Many of these deal with the way a teacher acknowledges students (verbal/non-verbal), the degree of motivation of students in class, the types of materials used (up-dated/out-dated), the types of activities programmed (boring/engaging), and the types of tasks (authentic/non-authentic). Indeed, it is enriching to have opportunities for reflection, interpretation, discussion, and decision-making on all of these aspects which are part of our daily lives as teachers. It builds trust among staff, improves teachers' practice and engages staff in serious commitment on our field, and 
it tells learners that they are important in the process, and that there is a profound interest in facilitating the acquisition of a foreign language.

Reflective teaching is undoubtedly a valid means towards effective teaching practices. Authors like Richards, Lockhart, Ramirez, and Wallace, have carried out studies to help English as a Second Language (ESL) teachers to teach reflectively. Bartlett (1990) has stated "for teachers of students of diverse ethnic backgrounds, becoming a reflective teacher offers a very real challenge" (p.214). This is true because teaching a second language involves many different factors, as the ones mentioned previously, that need to be considered, and which may affect both teaching and learning. Ramirez (1995) has added "in the second language classroom, reflective teaching may entail asking a number of "what" and "why" questions about teaching practices, reasons for language study, and explanations for students success or failure" (p.372). These questions will make teachers learn what is good or bad, what works or does not work, what motivates or frustrates learners, what facilitates or hinders learning, etc. Thus, language teachers in general need to know about linguistics, education, psychology, and any other field that may affect the teaching/learning process. Being theoretically illustrated will bridge the gap towards appropriate and efficient ESL/EFL instruction.

\subsubsection{Suggested procedures for reflective teaching in EFL contexts}

People unfamiliar with reflecting teaching may logically assume that reflective teaching is an isolated practice where we find a time and place to be alone and think. It is much more than that. It is a serious process. Reflection asks practitioners to stop, to slow down in order to notice, analyze, and inquire on what they are doing. It tells them to relate theory and practice, to evaluate both old and new teaching experiences, and to make interpretations on the situations encountered. In fact, reflective teaching, as defined by Cruickshank \& Applegate (1981) involves collaborative action research.

Collaborative involvement in action research strengthens the decisions that ESL/EFL teachers will make on professional practice through critical thinking, identification of classroom situations, planning, observation, reflection, and intervention. Ross (1997) has highlighted the importance of collaborative action research:

Collaborative action research is a powerful form of staff development because it is practice to theory rather than theory to practice. Teachers are encouraged to reach their own solutions and this is far more attractive and has more impact than being presented with ideals which cannot be attained. (cited in Burns, 1999). 
Answers obtained through action research are straightforward, and the authentic voices of concerned teachers are overheard as a source of change because they arise from the sharing of common problems which are realistic accounts of what truly happens in ESL/EFL classroom settings.

Kemmis and McTaggart (1982) have listed a number of benefits of action research:

- Thinking systematically about what happens in the classroom

- Implementing action where improvements are thought to be possible

- Monitoring and evaluating the effects of the action with a view to continuing the improvement

- Monitoring complex situations critically and practically

- Implementing flexible approach to classroom improvement through action and reflection

- Researching the real, complex and often confusing circumstances and constraints

- Recognizing and translating evolving ideas into action (cited in Burns, 1999, p. 16-17).

Collaborative action research requires the intervention of several participants to gather different perspectives of situations encountered in the classroom, and this is done through a variety of data collection procedures to ensure validity and reliability of the information gathered. The rich data obtained is thus triangulated or tested one against the other to mirror authentic classroom situations. Based on these findings, a great deal of analyses and reflection occurs in order to speculate reasons for these occurrences, provoking a plan of action or intervention on these happenings to later observe again for possible changes on the learning process. Much of this data is collected through the use of observational techniques such as observations, notes, diaries, journal entries, audio and video recordings, photographs or non-observational techniques like for example, surveys, interviews, and questionnaires.

Action research $(A R)$ can be very useful in getting to know our students. One of the major concerns in teaching English as a second or foreign language is the learner himself/herself. Probably this is one of the aspects teachers do not reflect on, or do not know of. Learners' cognitive styles affect learners' preferences for particular approaches to learning (Richards, 1999). Surveying their cognitive styles of learning can indicate whether teachers and learners approach learning the same way. This can be done with the help of surveys and questionnaires. Knowing this can also tell teachers what types of activities are favored by their learners so their implementation in class can facilitate the process to them. 
AR entails knowing about particular kinds of classroom activities, particular kinds of teacher behavior, particular grouping arrangements, particular sensory modes, such as visual, auditory and tactile learning, or even particular modes of learning on one's own outside class (Richards \& Lockhart, 1999). Questionnaires on learning strategies are surely very useful in determining which of these strategies our learners use or not. In fact, the strategies ESL/EFL learners use can make them successful or unsuccessful learners. Through questionnaires, the teacher can also research on learners' preferences whether they like learning English words by seeing or by hearing them, or they like all their mistakes to be corrected. We, teachers, many times assume what our learners interests and preferences are and that is how we plan our classes, but do we truly know our students wants, lacks, and likes? Action research is not a reflective process that happens once and that is it. On the contrary, it is an on-going process or cycle. One course of action will definitely not tell the teachers what facilitates or hinders learning. It is a recursive process during several sessions for several weeks and months to determine positive and negative experiences in teaching and learning English.

Another effective way of inquiring our own teaching and practices is by being committed in journal entries/ or teachers' diaries. This task demands making entries regularly, preferably daily, if possible, and immediately after class. It is important to review the notes while asking ourselves questions like "why do I do what I do?", "What is the role of students in my class?" Often times, this activity is individual. However, Richards \& Lockhart (1994) have pointed out that colleagues can share a journal and get together to discuss it. These journal entries help teachers understand themselves, understand their classes, and understand both the teacher's and learner's experiences as the lesson was developed. Wallace (1998) has explained that journals are excellent tools for reflection because

they provide effective means of identifying variables that are important to individual teachers and students; they enhance awareness about the way a teacher teaches and a student learns; they provide a first-hand account of teaching and learning experiences; they provide an on-going record of classroom events and teacher and learner reflections; they enable the researcher to relate classroom events and examine trends emerging from the diaries (p. 63).

Likewise, students' diaries are one of the most valuable instruments to collect rich and thick data from the learners when developing action research. Learners have so many things to say. They are the ones who are affected by our teaching, so getting feedback from them is productive, especially for inquiry faculty groups who can recall the information students 
provide and deeply analyze what they have to say of our teaching. The valuable aspect of diaries is that our students are telling us their feelings as they experience the language: if they liked the activities or not, if students feel intimidated, stressed, or anxious. Imagine the quantity of feedback teachers can obtain through this observational technique and the amount of reflection that can be done to make necessary changes for the benefit of our students. Indeed, diaries are very subjective and they are based only on students' perceptions of our classes, but this information can be triangulated with other observational data collection techniques such as video and audio recordings.

Observing one's teaching through video and audio recordings can be very valuable. Burns (1999) has clarified that they are good at "capturing in detail naturalistic interactions and verbatim utterances" (p. 94). Both video and audio recordings should be seen as an advantage rather than a disadvantage for reflective teaching, as an individual professional self-assessment and even for peer-assessment (faculty inquiry groups). Some faculty members might feel apprehensive to using them because they really picture what goes on in the classroom and these recordings are a vivid reflection of both teachers and students. If practitioners really want to inquire in their own teaching, they should see these tools as the means to an end; that is, the information portrayed in these recordings will answer those doubts that usually arise when we have finished a class. Examples of specific focus would be recording interactions of students (language used) in pair work or recording the language the teacher uses to give instruction. Even teacher's non-verbal communication (facial expressions) can be recorded if that is what the teacher is concerned about or wants to reflect about. After this is done, the teachers and a colleague can decide again on the date of the second observation to see if the suggestions work or not. That is why it is a on-going cycle. Observation is a determining factor in reflective teaching and it is used to collect information and not to evaluate it. Interestingly enough, Richards \& Lockhart (1994) pointed out that "teachers are often reluctant to take part in observation or related activities since observation is associated with evaluation" (p.12). When teachers observe colleagues they must not forget that they are expected to describe not judge; the idea is to learn from one another. To give trustworthiness to peer observation, several methods of observation can be employed like tally sheets, seating charts, and structured observation charts with specific titles. With tally sheets the observer can make instant marks of many things in class to determine the number of times they occur: use of the students' native language, use of teacher's specific metalanguage, times students raise their hands to answer questions, number of instances students go to the board, number of times girls participate versus boys in class discussions, 
number of times teachers use information questions or yes/no questions. Grids are also very useful because they contain headings that separate objective observation from subjective observation. These headings can be related to issues encountered in classes (Burns, 1999). A grid, for instance, could be designed on tasks (pre-, during, post-) which students have to perform in class. This information is placed in columns to facilitate the observation entries and relate the entries horizontally (task - grammar - vocabulary - negotiation) when the analyses is done.

Added to this, seating charts can be used to determine seating arrangements for every task in classroom settings. With this layout of class sessions by the observer, the teacher can see how seating arrangements took place in several classes and then revise them with a colleague to determine if they were appropriate or not. In addition, structured observation charts are very helpful because they also contain columns with headings on specific details which are worthwhile observing like learner error / teacher response vs the phase of the lesson, or stage of the lesson / teacher role / student role; another example can be lesson plan phases / time planned / actual lesson phases / actual time spent; or teacher question / student response / teacher feedback / student response to feedback (Wajnryb, 1992).

All of these observation methods can highlight aspects of the lesson and of the teacher's practice he or she is unaware of. Being a reflective practitioner/action researcher demands teaching, thinking back, describing, investigating reasons, discovering new understandings, deciding what to do next (Black, 2001). It calls for an appraisal of our own teaching, a willingness to change, an open mind to accept suggestions, and a serious attention to reflective practice. The answers to all our problems will not arise right away; it will take time, patience, responsibility, endurance, commitment, encouragement.

\section{Final remarks}

The process of reflection is not easy. In fact, just getting engaged in it might be difficult because of time constraints. Thinking about all the possible variables that affect the teaching/learning process while we are teaching or reflecting-in-action, might be overwhelming and confusing, especially for ESL/EFL teachers. Because it is almost humanly impossible to handle all the information at the same time, reflective teaching has been designed as a process. It means taking one step at a time, approaching knowledge with an open mind and a wholehearted attitude, and committed responsibility. in order to renew it through experience. Open-mindedness will create an interest in listening to all sides of an issue, and a willingness to 
seek out or create alternate possibilities; wholeheartedness will allow practitioners to selfevaluate themselves, their work, and existing structures and will also help them overcome fear and uncertainty; and last but not least, responsibility will lead to an extended concern and a desire to actively seek out the truth in order to solve the problems encountered again and again. This paper tries to demonstrate that reflective teaching is worth trying.

I am convinced that programs in teacher education should be designed to help student teachers become successful in-service teachers. Through guided reflection on field experiences, self-analysis and evaluation, professional development can be assured. Teachers must reflect, analyze, and adjust or change their practice whenever it is necessary; otherwise, thinking would actually become a waste of time. What really will make the difference when reflective/action research practice is performed is the fact that the results are empowering in helping ESL/EFL teachers become better teachers. The decision is ours. We can leave a mark in our students as well as in our teaching.

\section{REFERENCES}

Bartlett, L. (1990). Teacher development through reflective teaching. Jack. C. Richards \& D. Nunan. Second language teacher education. New York: Cambridge University Press.

Beyer, L. (1984). Field experience, ideology, and the development of critical reflectivity. Journal of Teaching for Education, 35 (3), 36-41.

Black, S. (2001). Thinking about teaching: How teachers can put reflection at the heart of their teaching. American School Board Journal, 188 (11), 1-7. Retrieved February 6 from the World Wide Web: http://www.asbj.com/2001/11/1101research.html

Burns, A. (1999). Collaborative action research for English language teachers. Cambridge: Cambridge University Press.

Collin, A. (1996). Re-thinking the relationship between theory and practice: Practitioners as map readers. British Journal of Guidance and Counseling, 24_(1), 67.

Cook, P.F. (1993). Defining reflective teaching: How has it been done for research? Paper presented at the annual Association of Teachers Conference in Los Angeles, California, February 16, 1993. Retrieved February 8, 2005 from the World Wide Web: http://www.edsnet.na/Resources/Reform\%20Forum/journal8/Journal\%208\%20Article\%204.pdf

Cruickshank, D. \& Applegate, J. (1981). Reflective teaching as a strategy for teacher growth. Educational Leadership, 38 (4), 553-554.

Dahlin, A. (1994). The teacher as a reflective professional. College Teaching, 42 (4), 57-60. 
Farrell, T. (1998). Reflective teaching: The principles and practices. English Teaching Forum, 36 (4), $10-17$.

Florez, M.C. (2004). Reflective practice in adult ESL settings. ERIC Digest. Retreived January 16, 2005 from the World Wide Web: http://www.ericdigests.org/2001-4/esl.html

Imel, S. (1992). Reflective practice in adult education. ERIC Digest, No. 122, Retrieved January 16, 2005 from the World Wide Web: http://www.ericdigests.org/1992-3/adult.htm

Joyce, B. \& Weil, M. (1996). Models of teaching. Boston, MA: Allyn and Bacon.

Leitch, R. \& Day, C. (2000). Action research and reflective practice: Towards a holistic view. Educational Action Research, 8 (1), 179 - 193.

Martin, M.W. \& Wedman, J. M. (1988). Identifying student teachers' routine and reflective thoughts through journal analysis. Educational and Psychological Research, 8 (4), 279-289.

Miller de Arechaga, G. (2001). Teacher development: Awareness, reflection and sharing. ELT Newsletter, No. 69. Retrieved January 22, 2005 from the World Wide Web: http://www.eltnewsletter.com/back/August2001/art692001.htm

Pickett, A. (1996). Reflective teaching practices and academic skills instruction. Retrieved January 5, 2004 from the World Wide Web: http://www.indiana.edu/1506/mod02/pickett.html

Ramirez, A. (1992). Creating contexts for second language acquisition: Theory and methods. White Plains, N.Y.: Longman Publishers.

Richards, J, C. (2000). Beyond training. Cambridge: Cambridge University Press.

Richards, J. C. \& Lockhart, C. (1994). Reflective teaching in second language classrooms. New York: Cambridge University Press.

Richert, A. (1990). Teaching teachers to reflect: A consideration of programme Structure. Journal of Curriculum Studies, 22 (6), 509-527.

Richardson, V. (1990). The evolution of reflective teaching and teacher education. R. T. Clift, W. R. Houston, \& M. C. Pugach, (Eds.), Encouraging Reflective Practice in Education (pp.). New York: Teachers College Press.

Simmons, J. M., and Schuette, M. K. Strengthening Teachers' Reflective Decision Making. Journal of Staff Development, 9 (3), Summer 1988: 18-27.

Schön, D. (1983). The reflective practitioner. New York: Basic Books, Inc.

. (1987). Educating the reflective practitioner: Strengthening teachers' reflective decision making. Journal of Staff Development, 9 (3), 18-27.

Tozer, S., Violas, P.C., \& Senese, G.B. (1995). School and society. McGraw-Hill. 
Wajnryb, R. (1999). Classroom observation tasks: A resource book for language Teachers and trainers. Cambridge: Cambridge University Press.

Wallace, M. J. (1991). Training foreign language teachers: A reflective approach. New York: Cambridge University Press.

Wallace, M. J. (1998). Action research for language teachers. Cambridge: Cambridge University Press. 